\title{
PENERAPAN PROGRAM SISTEM POIN DI SMK NEGERI 2 YOGYAKARTA
}

\section{APPLICATION OF POINT SISTEM PROGRAM AT SMK NEGERI 2 YOGYAKARTA}

\author{
Ipnu Wulandari \\ Filsafat dan Sosiologi Pendidikan, Kebijakan Pendidikan FIP UNY \\ ipnuwulandari19@gmail.com
}

\begin{abstract}
Abstrak
Penelitian ini bertujuan untuk mendeskripsikan penerapan program sistem poin di SMK Negeri 2 Yogyakarta. Pendekatan penelitian ini adalah kualitatif. Teknik pengumpulan data yang digunakan adalah wawancara, observasi, dan dokumentasi. Teknik analisis data menggunakan analisis data Miles dan Huberman yaitu pengumpulan data, reduksi data, penyajian data, penarikan kesimpulan. Uji keabsahan data menggunakan triangulasi sumber dan triangulasi teknik. Hasil penelitian adalah sebagai berikut : (1) penetapan dan persiapan program sistem poin dilakukan melalui perumusan tata tertib sekolah dengan hasil buku panduan tata tertib sekolah meliputi bentuk pelanggaran, poin pelanggaran, sanksi pelanggaran dan catatan pelanggaran. (2) pelaksanaan program sistem poin berjalan sesuai dengan tujuan sekolah untuk mendisiplinkan siswa, walaupun masih ada siswa yang melakukan pelanggaran.evaluasi program sistem poin dilakukan dengan menindaklanjuti dan memperbaharui isi dari buku panduan tata tertib sekolah setiap tahunnya untuk mengurangi tingkat pelanggaran tata tertib sekolah. (4) faktor pendukung program sistem poin yaitu adanya buku panduan tata tertib sekolah sebagai acuan guru maupun siswa untuk bersikap disiplin. Faktor penghambat program sistem poin yaitu kurangnya kesadaran warga sekolah untuk selalu bersikap disiplin tanpa adanya perintah.
\end{abstract}

Kata kunci: sistem poin, tata tertib sekolah

\begin{abstract}
This study aims to describe the application of the point system program at SMK Negeri 2 Yogyakarta. This research approach is qualitative. The data collection techniques used were interviews, observation and documentation. Data analysis techniques used data analysis by Miles and Huberman, namely data collection, data reduction, data presentation, drawing conclusions. Data validity test used source triangulation and technique triangulation. The results of the study are as follows: (1) the determination and preparation of the point system program is carried out by formulating school rules with the results of the school discipline by form of violation, violation points, violation sanctions and violation records. (2) the implementation of the point system program runs according to the school's goal of disciplining students, even though there are still students who commit violations. (3) evaluation of the point system program is carried out by following up and updating the contents of the school code of conduct each year to reduce the level of violations of school rules. (4) The supporting factor for the point system program is the existence of a school discipline guidebook as a reference for teachers and students to be disciplined. The inhibiting factor for the point system program is the lack of awareness of the school community to always be disciplined without any orders.
\end{abstract}

Keywords: point system, school rules. 


\section{PENDAHULUAN}

Undang-Undang Sistem Pendidikan Nasional Nomor 20 tahun 2003 Bab II pasal 3 menjelaskan bahwa, Pendidikan nasional memiliki fungsi untuk mengembangkan kemampuan dan membentuk watak serta peradaban bangsa yang bermartabat dalam rangka mencerdaskan kehidupan bangsa, bertujuan untuk berkembangnya potensi siswa agar menjadi manusia yang beriman dan bertakwa kepada Tuhan Yang Maha Esa, berakhlak mulia, sehat, cakap, kreatif, mandiri, dan menjadi warga negera yang demokratis dan bertanggung jawab. Pendidikan merupakan proses pengembangan kemampuan, sikap, dan perilaku ke arah yang lebih baik untuk kepentingan diri, keluarga, dan masyarakat. Pendidikan dapat dinyatakan berhasil jika mampu menghasilkan lulusan yang cerdas, kreatif, terampil, dan memiliki karakter yang kuat. Pendidikan nasional ialah untuk menciptakan generasi yang cerdas intelektual dan berakhlak mulia, namun kenyataannya aspek afektif dalam pembelajaran masih sering diabaikan. Prestasi dalam aspek kognitif masih sering dijadikan tolak ukur keberhasilan sebuah pembelajaran. Hal ini dapat dilihat dari hasil proses pembelajaran disekolah.

Sekolah adalah salah satu institusi pendidikan yang sangat berperan penting dalam pelaksanaan pendidikan. Sekolah memiliki peran mendidik dan memperbaiki tingkah laku siswa dalam lingkungan masyarakat. Hal ini tercermin dalam penegakan tata tertib atau kedisiplinan di sekolah. Fungsi dan tujuan tata tertib yang dibuat dan ditetapkan oleh pihak sekolah adalah untuk memperjelas apa yang boleh dan tidak boleh, sebagai batasan norma, tuntutan beretika dan bersikap sopan santun. Disiplin atau tata tertib yang diterapkan oleh sekolah harus dipatuhi oleh semua warga sekolah yang berada di lingkungan tersebut dan salah satunya siswa, karena disiplin merupakan salah satu hal yang sangat penting dalam proses pembentukan karakter siswa.

Kedisiplinan merupakan salah satu nilai karakter yang mengacu pada sikap perilaku, motivasi dan keterampilan siswa. Hal ini merupakan kebutuhan dasar, dalam rangka pembentukan dan pengembangan wataknya secara sehat. Tidak ada hal yang lebih penting dalam manajemen diri dibandingkan dengan disiplin. Selain pentingnya menemukan arah dan tujuan hidup yang jelas, disiplin juga merupakan syarat mutlak untuk mencapai cita-cita atau melaksanakan misi hidup. Seorang anak harus disiplin dalam mengembangkan dirinya dalam segala aspek, disiplin dalam mengelola waktu serta disiplin dalam melatih sumber daya alam setiap bidang yang dipilihnya. Setiap siswa memiliki cara tersendiri untuk mengembangkan sikap kedisiplinan pada dirinya. Begitu juga dengan lembaga sekolah, mereka akan membuat kegiatan yang dapat meningkatkan kedisiplinan siswa dalam membentuk karakter siswa. Provinsi DIY yang memiliki julukan kota pelajar tentunya sangat menjunjung tinggi nilai karakter khususnya pada nilai kedisiplinan. Hal ini terlihat dengan adanya Peraturan Walikota Yogyakarta No.57 Tahun 2011 Tentang Pedoman Penyusunan Tata Tertib Sekolah. Artinya dengan adanya tata tertib sekolah ini siswa ditutun untuk menaati segala peraturan yang nantinya akan menguji nilai kedisiplinan siswa. Provinsi DIY khususnya di sekolah menengah.. SMK Negeri 2 Yogyakarta adalah salah satu sekolah menengah kejuruan yang masih ditemukan beberapa masalah terhadap pelanggaran tata tertib sekolah, yaitu siswa datang terlambat, tidak segera masuk kelas ketika bel waktu istirahat habis, tidak menggunakan atribut sesuai dengan tata tertib sekolah, adanya penerapan hukuman fisik siswa bagi siswa yang sering terlambat untuk menyambut temannya di pagi hari. Siswa datang terlambat, selain dapat dilihat setiap pagi, keterlambatan siswa juga dapat dilihat dari presensi yang menggunakan fingerprint sehingga keterlambatan siswa dapat diketahui berapa detik atau menit siswa terlambat. Kurangnya sikap disiplin ini juga masuk dalam buku pelanggaran siswa yang dibuat sekolah dengan pedoman tata tertib sekolah yang telah dibuat apabila siswa melakukan pelanggaran tata tertib sekolah. Hal tersebut menuntut sekolah untuk menindak lanjutinya dengan menerapkan progam sistem poin dalam setiap pelanggaran yang dilakukan oleh siswa. Pelanggaran terhadap tata tertib sekolah tidak dapat dipisahkan dari siswa. Terkadang siswa melakukan pelanggaran tata tertib guna mencapai tujuan yang secara sengaja ingin dipertunjukkan. Misalnya, 
melakukan pelanggaran untuk mencari popularitas atau perhatian dari teman sebaya, pendidik maupun warga sekolah lainnya. Rendahnya kesadaran siswa untuk menaati tata tertib sekolah adalah masalah dan tanggung jawab bersama yang harus diselesaikan oleh semua pihak, oleh karena itu diperlukan suatu cara untuk mengatasi perilaku siswa yang melanggar aturan. Hal tersebut menuntut sekolah untuk menindaklanjutinya dengan menerapkan progam sistem poin dalam setiap pelanggaran yang dilakukan oleh siswa.

Sistem poin merupakan program sekolah untuk mengurangi tingkat pelanggaran yang dilakukan oleh siswa. Siswa yang melanggar aturan akan diberikan sanksi yang berupa hukuman. Jenis hukuman ditentukan dari akumulasi jumlah poin yang didapat anak saat melakukan pelanggaran. Sistem poin diberlakukan dalam tata tertib sekolah. Masing-masing peraturan diberikan poin yang berbeda sesuai dengan besar atau kecilnya pelanggaran, namun dalam penerapannya sekolah tidak hanya fokus pada poin pelanggaran saja, tetapi sekolah juga memberikan poin penghargaan bagi siswa berprestasi. Salah satu poin penghargaan yang diberikan sekolah misalnya anak tersebut mendapatkan juara pertama dalam lomba Olimpiade Siswa Nasional, sehingga poin penghargaan siswa tersebut bisa digunakan untuk mengurangi poin pelanggaran yang didapat siswa tersebut sebelumnya.

Berdasarkan hasil prapenelitian tersebut juga diketahui bahwa SMK Negeri 2 Yogyakarta dulunya adalah sekolah yang memiliki image bahwa siswa di sekolah tersebut terkenal dengan siswa-siswa yang sering melakukan pelanggaran terhadap tata tertib sekolah. Namun pada akhirnya SMK Negeri 2 Yogyakarta ini memiliki cara untuk menghilangkan image tersebut dengan membuat program sekolah untuk mengurangi pelanggaran tata tertib yaitu dengan menerapkan program sistem poin. Oleh karena itu, penelitian ini bermaksud untuk mengetahui pelaksanaan penerapan program sistem poin di SMK Negeri 2 Yogyakarta.

\section{METODE PENELITIAN}

\section{Jenis Penelitian}

Pendekatan yang digunakan dalam penelitian ini adalah pendekatan kualiatif. penelitian ini termasuk dalam jenis penelitian deskriptif kualitatif. Penelitian deskriptif kualitatif berarti bahwa dalam penelitian ini, peneliti mendiskripsikan objek. Penggunaan metode kualitatif deskriptif pada penelitian ini, penulis memusatkan hasil penelitian dengan mempertimbangkan dari pungumpulan data di lapangan. Penulis memaparkan bahwa penelitian kualitatif adalah penelitian yang menggunakan pendekatan natural setting, karena metode ini digunakan untuk mendapatkan data yang mendalam, suatu data yang mengandung makna.

\section{Waktu dan Tempat Penelitian}

Penelitian ini dilaksanakan di SMK Negeri 2 Yogyakarta Jl.AM. Sangaji No.47, Cokrodiningratan, Jetis, Kota Yogyakarta, DIY 55233. Penelitian dilaksanakan dari bulan Oktober 2019 samapi bulan November 2019.

\section{Objek dan Subjek Penelitian}

Obyek dalam penelitian ini adalah segala hal yang berkaitan dengan proses penerapan dan penanganan program sistem poin di SMK Negeri 2 Yogyakarta. Subyek penelitian ini adalah wakil kepala kesiswaan, guru BK, tim budaya, wali kelas, dan siswa SMK Negeri 2 Yogyakarta. Peneliti sengaja tidak membatasi jumlah subyek dalam penelitian ini, karena dalam penelitian kualitatif, jumlah subyek yang diteliti tidak dibatasi, yang terpenting adalah kejenuhan data.

\section{Teknik Pengumpulan Data}

Penelitian ini peneliti menggunakan teknik pengumpulan data berupa observasi, wawancara dan dokumentasi.

\section{Teknik Analisis Data}

Teknis analisis data yang digunakan adalah model interaktif dari Miles dan Huberman terdiri dari empat alur kegiatan yang terjadi secara bersama-sama yaitu 
pengumpulan data, reduksi data, penyajian data, penarikan kesimpulan atau verifikasi.

\section{Teknik Keabsahan Data}

Uji keabsahan data dalam penelitian ini menggunakan uji kredibilitas dengan melakukan triangulasi yaitu untuk menguji kredibilitas data yang dilakukan dengan cara mengecek data yang telah diperoleh melalui beberapa sumber dan juga menggunakan triangulasi teknik yaitu untuk menguji kredibilitas data yang dilakukan dengan cara mengecek data kepada sumber yang sama dengan teknik yang berbeda.

\section{HASIL PENELITIAN DAN PEMBAHASAN}

Penerapan program sistem poin di SMK Negeri 2 Yogyakarta merupakan salah satu alternatif yang dilakukan untuk memecahkan masalah tentang kedisiplinan. Dimana pada pelaksanaannya seringkali menemukan berbagai kendala. Rumusan-rumusan yang telah ditetapkan secara terencana dapat saja berbeda di lapangan. Hal ini disebabkan berbagai faktor yang sering mempengaruhi pelaksanaan program sistem poin di sekolah. Program sistem poin dibentuk karena semakin banyaknya tingkat pelanggaran siswa terhadap tata tertib sekolah dan dalam upaya menanamkan salah satu sikap pendidikan karakter yaitu kedisiplinan. Sistem poin merupakan program sekolah untuk mengurangi tingkat pelanggaran yang dilakukan oleh siswa. Siswa yang melanggar aturan akan diberikan sanksi berupa hukuman dengan akumulasi jumlah poin yang didapat anak saat melakukan pelanggaran, sehingga pelaksanaannya dibutuhkan persiapan dan penetapan, pelaksanaan dan evaluasi terhadap program sistem poin yang sedang dilakukan di SMK Negeri 2 Yogyakarta.

\section{Penetapan dan persiapan program sistem poin}

Penetapan program sistem poin di SMK Negeri 2 Yogyakarta berjalan sesuai dengan peraturan walikota Yogyakarta no.57 tahun 2011 tentang pedoman penyusunan tata tertib sekolah. Namun untuk menetapkan tata tertib, sekolah membutuhkan sanksi agar siswa taat terhadap tata tertib yang dibuat sekolah. SMK Negeri 2 Yogyakarta memiliki perencanaan dalam pelaksanaan program sistem poin. Sehingga dalam membentuk isi dari sistem poin ini sekolah membuatnya secara adil, yaitu dengan persetujuan pihak-pihak yang berkaitan dengan sistem poin tersebut. Proses penetapan sistem poin di SMK Negeri 2 Yogyakarta melibatkan tim kesiswaan yang terdiri dari staff sekolah, waka, kepala sekolah, tim BK, tim budaya, MPO dan perwakilan siswa atau OSIS.

\section{Pelaksanaan program sistem poin}

Dalam tahap pelaksanaan, peneliti memfokuskan pada hasil obsrvasi dan pengamatan dari program yang diterapkan di sekolah. Pada pelaksanaan program sistem poin, sekolah memberikan buku panduan tata tertib sekolah yang disampaikan bersamaan dengan sosialisasi siswa dan orangtua wali pada saat tahun ajaran baru di SMK Negeri 2 Yogyakarta. Setiap pelanggaran akan ada poin dan sanksi yang diberikan kepada siswa untuk ketidakhadiran tanpa keterangan, berpakaian tidak sesuai dengan standar sekolah dan lain sebaginya. Dengan adanya sosialisasi dan buku panduan tata tertib ini diharapkan orangtua wali juga dapat ikut mengawasi siswa agar tidak melakukan pelanggaran tata tertib sekolah. Buku panduan tata tertib ini berlaku selama 3 tahun, namun jika pada suatu hari terdapat perubahan pada buku panduan tata tertib, sekolah akan menyampaikan surat edaran terkait perubahan tersebut. Buku panduan tata tertib ini berisi tentang bentuk pelanggaran, poin pelanggaran, sanksi pelanggaran dan catatan pelanggaran, sehingga dari buku panduan tersebut tim budaya dapat melihat pelanggaran apa saja yang dilakukan siswa.

\section{Evaluasi program sistem poin}

Evaluasi program sistem poin dilakukan setiap akhir tahun. hal ini untuk memonitoring apakah program ini berjalan sesuai dengan tujuan sekolah atau tidak. Pada dasarnya suatu program pendidikan selalu membutuhkan evaluasi entah pada proses perumusan, persiapan maupun pelaksanaannya untuk mengetahui ketercapaian target yang di tetapkan pada saat pembuatan program. Hal ini juga berlaku pada program sistem poin di SMK Negeri 2 Yogyakarta dimana setiap tahunnya akan dilakukan evaluasi terkait ketercapaian tujuan yang di tetapkan. Dalam menangani siswa yang bermasalah tidak selalu dengan poin, karena poin hanya sebagai tolak ukur perilaku pelanggaran yang dikuantitaskan. Disisi lain siswa yang melakukan pelanggaran yang dapat dikategorikan dalam pelanggaran ringan misalnya terlambat, tidak 
bawa buku litersi atau atribut seragam yang tidak lengkap, hukuman yang mereka dapat bisa berupa hukuman fisik yang tentunya dapat mengedukasi siswa. Seperti yang dilakukan di SMK Negeri 2 Yogyakarta, mereka memberikan hukuman fisik berupa misalnya siswa yang sering terlambat diberikan sanksi keterlambatan dengan cara setiap pagi selama waktu yang ditentukan harus menyambut siswa lain yang datang, siswa harus melaksanakan solat dhuha dan membersihkan mushola. Hukuman fisik ini dapat mengedukasi siswa untuk memperkuat akhlaknya dalam menjalankan ibadah sebagai umat muslim.

\section{Faktor penghambat dan faktor pendukung}

Berdasarkan hasil observasi dan wawancara yang dilakukan, bahwa program sistem poin ini didukung dengan fasilitas buku panduan tata tertib sekolah terdapat keterangan poin yang memiliki sanksi ringan atau berat juga beberapa peraturan tata tertib yang harus ditaati setiap hari, sehingga harapannya seluruh warga sekolah ikut bekerjasama dalam pelaksanaan program sistem poin yang telah diterapkan di SMK Negeri 2 Yogyakarta. Faktor penghambat dalam pelaksanaan sistem poin ini adalah guru sendiri yang kadang tidak memperdulikan hal-hal kecil dan enggan menegurnya yang mengacu pada kelakuan, kerajinan atau kerapian, sehingga dibutuhkan kesadaran warga sekolah untuk menaati peraturan tata tertib sekolah.

\section{Pembahasan}

Pada dasarnya program sistem poin diterapkan karena tingginya tingkat pelanggaran siswa terhadap tata tertib. Tata tertib merupakan peraturan atau norma yang mengharuskan para siswa untuk mematuhinya. Tata tertib sekolah di SMK Negeri 2 Yogyakarta mengarah pada kedisiplinan yang menjadi salah satu kunci kesadaran yang muncul dalam diri siswa untuk menaati peraturan,nilai dan norma yang berlaku di sekolah. Penggunaan sistem poin tidak dapat dijadikan potokan siswa dalam melanggar peraturan sekolah. Walaupun siswa mendapatkan poin dalam pelanggaran, seorang pendidik yang memberikan sanksi juga harus mempertimbangkan alasan siswa mengapa melakukan pelanggaran.

1. Penetapan dan persiapan program sistem poin

Berdasarkan Peraturan Walikota

Yogyakarta no.57 tahun 2011 tentang pedoman penyusunan tata tertib sekolah, dari pihak sekolah kemudian memusyawarahkan pembuatan perumusan tata tertib sekolah yang dilakukan oleh tim kesiswaan yang terdiri dari staff sekolah, waka, kepala sekolah, tim BK, tim budaya, MPO dan perwakilan siswa atau OSIS . Hal ini dimaksudkan untuk mengakomodir aspirasi dari berbagai pihak yang ada di lingkungan sekolah. Selanjutnya hasil musyawarah yang dirumuskan, ditetapkan menjadi peraturan tata tertib sekolah dimana hasil perumusannya berbentuk buku panduan tata tertib sekolah. buku panduan tata tertib sekolah ini berisi tentang bentuk pelanggaran, sanksi pelanggaran, poin pelanggaran dan catatan pelanggaran. mengurangi tingkat pelanggaran siswa dan membuat siswa lebih disiplin waktu dan disiplin perilaku. Karena semua peraturan yang tercantum dalam buku panduan tata tertib sekolah lebih bisa ditaati. Walaupun tidak berupa hukuman, sistem poin adalah salah satu alternatif untuk mendisiplinkan siswa. Dengan adanya sistem poin ini siswa bisa mengetahui telah melakukan pelanggaran berapa kali dan siswa lebih jera untuk mengulangi kesalahannya kembali. Bukan hanya manfaat untuk siswa tetapi juga manfaat untu guru dan manfaat untuk sekolah. Manfaat penerapan sistem poin bagi sekolah adalah kedisiplinan siswa bisa lebih tercapai, siswa dapat terbiasa tertib di sekolah. Aspek dalam bentuk pelanggaran yang tertera dalam buku panduan tata tertib sekolah meliputi kelakuan, kerajinan dan kerapian. Sedang dalam sanksi pelanggaran dilihat dari bobot poin pelanggaran selama 1 tahun yang dihitung secara komulatif dicatat oleh wali kelas yang bersangkutan dan dilanjutkan oleh wali kelas berikutnya. Jika sampai memenuhi jumlah yang ditentukan maka akan diproses sebagaimana mestinya yang diberlakukan selama menjadi siswa di SMK Negeri 2 Yogyakarta.

2. Pelaksanaan program sistem poin Dalam pelaksanaannya, program sistem poin merupakan tanggung jawab dar Tim Budaya, Wali Kelas, Guru BK, Kesiswaan atau tim khusus yang dibentuk dengan wewenang masing-masing. Namun untuk membantu mengurangi tingkat pelanggaran yang dilakukan siswa semua guru memiliki hak dan kewajiban dalam melakukan pembinaan dan penertiban terhadap siswa. 
3. Evaluasi program sistem poin

Dalam pelaksanaannya, SMK Negeri

2 Yogyakarta mengambil keputusan untuk melanjutkan pelaksanaan program sistem poin dengan pembaharuan buku panduan tata tertib sekolah di setiap akhir tahun. hal ini dilakukan untuk merespons siswa untuk selalu menaati tata tertib sekolah dan tidak melakukan pelanggaran. Meskipun ada beberapa pelanggaran yang setiap harinya masih sering dilakukan oleh siswa seperti terlambat masuk sekolah atau kelas, ketidakhadiran tanpa keterangan, dan lain sebagainya. Hal ini terjadi karena karakter siswa berbeda-beda dan pihak sekolah juga harus memahami alas an yang bisa memungkinkan siswa melakukan pelanggaran tersebut. Namun dengan demikian penerapan program sistem poin yang dilakukan SMK Negeri 2 Yogyakarta dapat berjalan dengan lancar karena adanya dukungan dari seluruh pihak sekolah yang mendukung adanya sistem poin. Hal ini karena dengan penerepan program sistem poin di SMK Negeri 2 Yogyakarta siswa bisa mendapat berbagai manfaat, yaitu dapat mengurangi tingkat pelanggaran siswa dan membuat siswa lebih disiplin waktu dan disiplin perilaku. Karena semua peraturan yang tercantum dalam buku panduan tata tertib sekolah lebih bisa ditaati. Walaupun tidak berupa hukuman, sistem poin adalah salah satu alternatif untuk mendisiplinkan siswa. Dengan adanya sistem poin ini siswa bisa mengetahui telah melakukan pelanggaran berapa kali dan siswa lebih jera untuk mengulangi kesalahannya kembali. Bukan hanya manfaat untuk siswa tetapi juga manfaat untu guru dan manfaat untuk sekolah. Manfaat penerapan sistem poin bagi sekolah adalah kedisiplinan siswa bisa lebih tercapai, siswa dapat terbiasa tertib di sekolah.

4. Faktor penghambat dan faktor pendukung

Faktor pendukung dalam pelaksanaan sistem poin ini adalah adanya dukungan dari dinas pendidikan dan warga sekolahuntuk menerapakan nilai karakter khususnya disiplin dan dapat mengurangu tingkat pelanggaran siswa. Faktor penghambatnya adalah warga sekolah kurang konsisten dalam pelaksanaan sistem poin. Terkadang banyak guru-guru yang enggan menegur kalau siswa melakukan pelanggaran contohnya ada siswa yang bajunya tidak di masukkan, pasti ada guru yang mengingatkan tapi ada juga guru yang tidak peduli dengan hal ini. Hal ini terjadi karena kurangnya sosialisasi terhadap warga sekolah tentang penerapan program sistem poin di SMK Negeri 2 Yogyakarta.

\section{KESIMPULAN DAN SARAN Kesimpulan}

Berdasarkan analisis dari hasil observasi dan wawancara mengenai penerapan program sistem poin di SMK Negeri 2 Yogyakarta maka dapat disimpulkan bahwa penerapan sistem poin yang dilakukan di SMK Negeri 2 Yogyakarta dilakukan dengan tahapan persiapan dan penetapan program sistem poin, pelaksanaan program sistem poin dan evaluasi program sistem poin.

1. Persiapan dan penetapan program sistem poin dilakukan dengan merumuskan tata tertib sekolah yang berdasarkan Peraturan Walikota Yogyakarta no. 57 tahun 2011 tentang Penyusunan Tata Tertib Sekolah dengan melibatkan Tim Budaya, OSIS atau MPK, Wali Kelas, Guru BK, Kesiswaan, atau tim khusus yang dibentuk dengan wewenang masing-masing. Hasil dari perumusan tersebut berupa buku panduan tata tertib sekolah yang kemudian disosialisasikan kepada seluruh warga sekolah.

2. Pelaksanaan program sistem poin dilakukan sesui dengan buku panduan tata tertib sekolah dimana dalam penerapannya di SMK Negeri 2 Yogyakarta cukup efektif dalam mengurangi tingkat pelanggaran siswa. Walaupun belum maksimal dan masih ada siswa yang melanggar, sehingga wali kelas memberikan perwalian sebagi bentuk pembinaan terhadap siswa untuk selalu bersikap disiplin dalam setiap kegitatan yang dilakukan sekolah.

Evaluasi program sistem poin di SMK Negeri 2 Yogyakarta dilakukan pada akhir tahun sebagai bentuk keputusan apakah sistem poin akan diterapkan kembali dengan pembaharuan atau tidak, atau sistem poin tidak dilanjutkan. Namun dapat diperhatikan bahwa penerapan sistem poin dapat berjalan sesuai dengan tujuan sekolah untuk mendisiplinkan siswa. Walupun masih ada 
siswa yang melanggar namun dengan bantuan buku panduan tata tertib sekolah yang mendukung penerapan sistem poin dapat membantu pendidik dalam mengontrol siswa untuk tetap mengikuti peraturan yang berlaku di sekolah. Dengan pemberian poin bagi yang melanggar tata tertib dan juga pemberian reward bagi siswa berprestasi yang tercantum dalam buku panduan tata tertib sekolah. Sehingga dengan adanya penerapan sistem poin ini siswa lebih bisa berhati-hati dalam mengambil setiap tindakan yang dilakukan, karena bagaimapun setiap pelanggaran mereka menjadi poin penting yang dapat mengurangi kualitas sistem belajar mereka sendiri. Dengan demikian siswa akan merasa selalu diawasi sehingga dengan begitu lambat laun siswa akan terbiasa dengan peraturan sekolah yang ada tanpa harus diperintahkan. Atas dasar inilah SMK Negeri 2 Yogyakarta menerapkan program sistem poin di sekolah.

\section{Saran}

Diharapkan seluruh warga sekolah SMK Negeri 2 Yogyakarta ikut berpartisipasi dalam pembentukan karakter siswa khususnya dalam hal pendisiplinan. Karena sistem poin hanya salah satu sarana sekolah untuk membiasakan siswa untuk selalu menaati peraturan yang berlaku di sekolah.

\section{DAFTAR PUSTAKA}

Anitah, S. 2016. Strategi Perencanaan Pembelajaran. Jakarta: PT Bina Aksara

Aulia Silfiana, dkk. 2012. Landasan Undang-Undang Sisdiknas.

Makalah. Fakultas Keguruan dan Ilmu Pendidikan Universitas Muhammadiyah Surakarta.

Diakses pada laman

https://www.slideshare.net/firlita nurulkharisma/makalah-undangundang-sistem-pendidikan- nasional Pada hari Sabtu, 22 September 2018, Pukul 13.34 WIB.

Arikunto, S. 2006. Prosedur Penelitian Suatu Pendekatan Praktet: Jakarta: PT Bina Aksara

Cahyo Fitriwati. 2015. Penerapan Sistem Poin dalam Menanggulangi Siswa Yang Melanggar Aturan di SMA N 2
Pontianak. Skripsi. Diakses pada

lamanhttps://core.ac.uk/display/1 45204938Pada hari Rabu, 10

Oktober 2018, Pukul 20.45 WIB. Dewantara,K.H. 2013. Bagian 1 : Pendidikan. Yogyakarta: UST Press. Eldomenico. 2010. Peraturan Sekolah : Disiplin, Ketertiban, Pelanggaran, dan Hukuman. (http://eldomenico.wordpress.co m/2010/05/25/peraturan-

sekolahdisiplin-ketertiban-pelanggarandan-hukuman/)di akses tanggal 11 Oktober 2018, Pukul 10.15 WIB

Fattah, Nanang. 2013. Analisis Kebijakan Pendidikan. Bandung: PT Remaja Rosdakarya.

Gaza, Mamiq. 2012. Bijak Menghukum Siswa. Jogjakarta: Ar-Ruzz Media.

Hasbullah. 2016. Kebijakan Pendidikan : Dalam Prespektif Teori, Aplikasi dan Kondisi Objektif Pendidikan di Indonesia. Jakarta: PT Raja Grafindo Persada.

Miles dan Huberman. 1992. Analisis Data Kualitatif. Jakarta: Universitas Indonesia Press.

Moleong, Lexi. 2002. Metodologi Penelitian Kualitatif. Bandung : PT Remaja Rosdakarya.

Rohman, Arif. 2012. Kebijakan Pendidikan Analisis Dinamika Formulasi dan Implementasi. Yogyakarta: Ombak.

Sugiyono, 2010. Metode Penelitian Pendidikan Pendekatan Kuantitatif, Kualitatif dan $R \quad \& D$. Bandung: Alfabeta.

Suharno. 2016. Dasar-Dasar Kebijakan Publik Kajian Proses dan Analisis Kebijakan. Yogyakarta : Ombak

UlyInayati Taqiyya. 2013. Implementasi Kebijakan Penerapan Sistem Poin dalam Mengurangi Tingkat Pelanggaran Siswa pada SMA N 1 Jekulo Kudus. Skripsi. FakultasI lmu Sosial Universitas Negeri Semarang. Diakses pada laman https://lib.unnes.ac.id/18483/1/3301409 024

.pdf Pada hari Rabu, 10 Oktober 2018, Pukul 20.45 WIB.

Watah, MJ.2005. Pengembangan Disiplin dan Pembentukan Moral pada Anak Usia Dini. Jakarta: Depdiknas 
William N. Dunn, 2003. Pengantar Analisis Kebijakan Publik. Yogyakarta: University Press.

Yanuar A. 2012. Jenis-Jenis Hukuman

Edukatif. Jogjakarta: DIVA Press.

Zidni, Huda Tsaniyati. 2017. Implementasi Tata Tertib Sistem Poin dalam Pembentukan

Akhlak Siswa di SD IslamDrul Mu'min, Kota Tangerang. Skripsi. Fakultas Ilmu Tarbiyah dan Keguruan Universitas Islam Negerti Syarif Hidayatullah Jakarta. Diakes pada laman https://repository.uinjkt.ac.id pada hari Sabtu, 16 Mei 202, Pukul 21.45 WIB. 